Available online on 15.02.2020 at http://ajprd.com
(c) 2013-20, publisher and licensee AJPRD, This is an Open Access article which permits unrestricted non-
commercial use, provided the original work is properly cited

Open Access

Research Article

\title{
ISOLATION AND CHARACTERIZATION COLLAGEN OF PATIN FISH SKIN (Pangasius Sp.)
}

\author{
Valentina Girsang*, Julia Reveny, Marline Nainggolan \\ Faculty of Pharmacy, Universitas Sumatera Utara,Medan, Indonesia
}

\begin{abstract}
A B S T R A C T
Objective: This study aims to isolate and characterize the collagen isolated from the skin of patin fish.

Method: Collagen isolation consisted of three steps, namely deproteinization process using $\mathrm{NaOH}$ solution concentration of $0,05 \mathrm{M}$ and long soaking time for $3 \times 24$ hours; immersion in $\mathrm{CH}_{3} \mathrm{COOH}$ solution with a concentration of $0,05 \mathrm{M}$ and long soaking time $3 \times 24$ hours; Furthermore, collagen was extracted with water at $40^{\circ} \mathrm{C}$ for 2 hours. The isolated collagen was tested for characteristics including chemical and physical properties compared to commercial collagen.

Results: Chemical characteristics of collagen isolated from patin fish skin isolation compared to commercial collagen, respectively: $6,55 \%$ and $6,68 \%$ water content; ash content of $0,19 \%$ and $0,18 \%$; protein content $93,63 \%$ and $97,42 \%$ and fat content $0,41 \%$ and $0,30 \%$; The metal content in the collagen isolated from the skin of patin fish and commercial collagen is below the threshold $(\mathrm{Pb}) ; 0,5 \mathrm{mg} / \mathrm{kg}$. Amino acid test results from patin fish skin collagen obtained glycine $(234381,88 \mathrm{mg} / \mathrm{kg})$, proline $(109404,17 \mathrm{mg} / \mathrm{kg})$, alanine $(83988,79 \mathrm{mg} / \mathrm{kg})$, arginine $(80918,44 \mathrm{mg} / \mathrm{kg}) \mathrm{and} \mathrm{glutamate}(87315,88 \mathrm{mg} / \mathrm{kg})$. The physical characteristics of the patin fish skin collagen showed the presence of amide group A $\left(3286,7 \mathrm{~cm}^{-1}\right)$, amide B $\left(2947,23 \mathrm{~cm}^{-1}\right)$, amide I $\left(1651,07 \mathrm{~cm}^{-1}\right)$, amide II $\left(1450,47 \mathrm{~cm}^{-1}\right)$, and amide III $\left(1246,02 \mathrm{~cm}^{-1}\right)$.

Conclusion: Patin fish skin can be isolated into collagen that meets the quality requirements of collagen as a cosmetic preparation.
\end{abstract}

Keywords: patin fish, isolation, characterization, collagen, skin

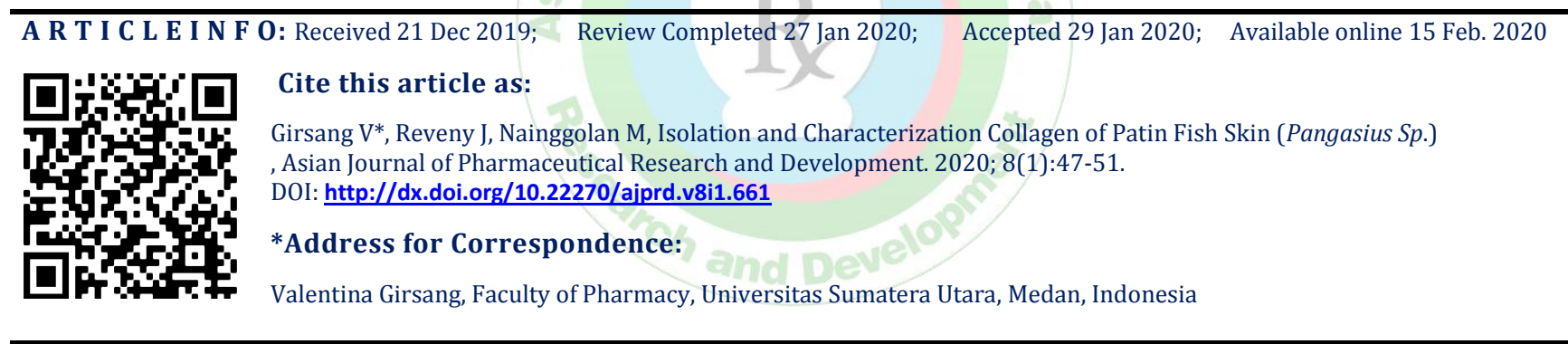

\section{INTRODUCTION}

$\mathrm{I}$ ndonesia is a country that is rich in fish potential, both capture fisheries and aquaculture. One of the fish that has been widely cultivated in Indonesia is patin fish. Patin fish is a freshwater fish species. This type of fish is usually used as consumption fish. Therefore, many entrepreneurs who cultivate patin fish.Patin fish is a popular fish commodity and its production in Indonesia has increased significantly over the last few years, namely in 2015 its production increased by $11,53 \%$ to 80 thousand tons in $2015^{1 .}$ Patin is one of the freshwater fish very popular consumed all over the world.

In general, the processing of patin fish in Indonesia produces fillet products which are then sold as fresh or frozen fillets. The yield in the process of patin fish fillet processing is around $45 \%$, the rest including the contents of the stomach, abdominal fat, bones and skin of $55 \%$ has not been used optimally ${ }^{2}$. The fish processing process generally produces waste up to $50 \%$ of the total weight of the processed fish ${ }^{3}$. Some of the waste in patin fish such as skin can still be utilized as a high-value product, for example collagen.

Collagen itself is a connective tissue protein that is widely used as an additive in food, pharmaceuticals and cosmetics. Because the benefits of collagen are numerous, so the need for collagen also increases. This shows the potential for the utilization of patin fish (Pangasius sp.) Skin as a source of collagen. For this reason, researchers will isolate collagen, as well as the characterization of collagen from patin fish skin.

\section{MATERIALS AND METHODS}

\section{Materials and Tools}

The materials used in this study include patin fish (Pangasius Sp.) Obtained from UD. Samosir on JalanBunga Sakura No.53, Tj.Selamat, Kec.Medan Tuntung. For collagen extraction $\mathrm{NaOH}$, aquades and $\mathrm{CH}_{3} \mathrm{COOH}$ are used. The tools used in this study include glass beaker, erlenmeyer, measuring cup, spatula, measuring flask, thermometer, analytical balance, digital balance, hotplate and refrigerator. 


\section{Research Methods}

\section{Preparation of patin fish skin raw material}

The material used for the isolation of collagen comes from the skin of patin fish obtained from traditional markets. Patin fish skin is cleaned and separated from the meat that is still remaining attached to the skin. The patin fish skin sample is cut into pieces and then stored in a freezer $\left(15^{\circ} \mathrm{C}\right)$ if the sample is not used immediately.

\section{Isolation of Patin Fish Skin Collagen}

The process of extracting and isolating collagen from patin fish skin samples using a modification method by isolation with acid ${ }^{4}$.Patin fish skin sample weighed as much as 50 grams. The sample was then removed from non-collagen protein and degreasing by immersing the chopped sample in a $\mathrm{NaOH}$ solution $0,05 \mathrm{M}$. The $\mathrm{NaOH}$ solvent used for the skin was $300 \mathrm{ml}$. This immersion was carried out for $3 \times 24$ hours and every day the $0,05 \mathrm{M} \mathrm{NaOH}$ solvent was replaced with a new one. The skin of patin fish is washed with aquadest until the $\mathrm{pH}$ of the sample reaches $\mathrm{pH} 7$. The collagen extraction process is carried out with a $\mathrm{CH}_{3} \mathrm{COOH}$ solution at a concentration of $0,05 \mathrm{M}$. The solvent used for patin fish skin is $300 \mathrm{ml}$ with an incubation time of $3 \times 24$ hours. The extraction product is filtered with a plastic filter to separate the residue from the extract. The skin soaking from $\mathrm{CH}_{3} \mathrm{COOH}$ solution is washed with distilled water until it reaches a neutral $\mathrm{pH}$ before proceeding to the third step, extraction with water at $40^{\circ} \mathrm{C}$ for 2 hours with the ratio between skin and water is $1: 1(\mathrm{w} / \mathrm{v})$. The result of extraction is water soluble collagen, which is then dried using an oven to obtain collagen in powder form.

\section{Analysis of the Characteristics of Patin Fish Skin Collagen}

This stage aims to obtain collagen characteristics that include chemical and physical characteristics. Chemical characteristics include proximate analysis and type of amino acid 5, 6, while physical characteristics measured include functional groups using FTIR spectrophotometer, metal content, $\mathrm{pH}^{7,8}$.

\section{RESULTS AND DISCUSSION}

\section{Isolation of Patin fish Skin Collagen}

Collagen isolation or collagen manufacturing begins with the deproteinization treatment, which is the removal of non-collagen proteins using an alkaline solution. Soaking in alkali can also eliminate the presence of fat in the ingredients. The use of alkaline solutions in skin pretreatment is more effective in the process of releasing non-collagen proteins and only causes a low level of collagen loss compared to the use of acid solutions ${ }^{9}$.

In the second step, skin immersion was carried out in 0,05 $\mathrm{M}$ acetic acid solution for $3 \times 24$ hours. Acid pretreatment is needed to change the structure of collagen fibers, so that it will facilitate the extraction process at a later stage. Immersion in acid causes swelling of the skin due to the entry of water into the collagen fibers. The entry of water into collagen fibers is due to electrostatic forces between polar groups in collagen fibers and $\mathrm{H}^{+}$from acids, or the formation of hydrogen bonds between non-polar groups in collagen fibers and $\mathrm{H}^{+}$from acids ${ }^{10}$. This swelling is important because it can support damage to the collagen fiber structure, through disruption of non-covalent bonds and ultimately facilitate extraction and increase collagen solubility.

The immersion skin is extracted with water, aquabides, with a skin and water ratio of 1: 1 using a temperature of $40^{\circ} \mathrm{C}$ for 2 hours. The process of heating the skin in warm water causes continued damage to hydrogen and covalent bonds that had previously taken place during the process of soaking acetic acid.

The $40^{\circ} \mathrm{C}$ temperature was chosen in order to avoid the degradation of collagen to gelatin during extraction. This is based on the opinion of Karim and Bhat which states that the temperature of $40^{\circ} \mathrm{C}$ is the transition temperature of helical transformation into a roll form which leads to the formation of soluble gelatin. The results of skin extraction with water in the form of water-soluble collagen, then dried with an oven to obtain collagen in powder form ${ }^{11}$.

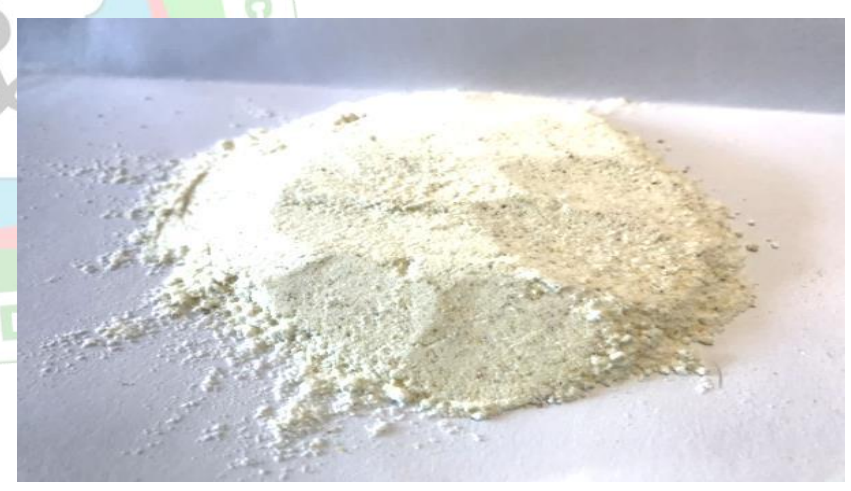

Figure 1.Patin fish skin collagen

\section{Analysis of Collagen Characteristics of Patin Fish Skin}

The results of the analysis of water content, ash content, protein content and fat content of patin fish skin collagen and commercial collagen can be seen in Table 1.

Table 1:. Data analysis of water content, ash content, protein content and fat content of patin fish skin collagen and commercial collagen

\begin{tabular}{|l|l|l|l|}
\hline Analysis & $\begin{array}{l}\text { Skin Collagen } \\
\text { Patin fish }\end{array}$ & Commercial Collagen & $\begin{array}{l}\text { Collagen quality requirements } \\
\text { SNI 8076:2014 }\end{array}$ \\
\hline Water content & $6,55 \%$ & $6,68 \%$ & $\leq 12$ \\
\hline Ash content & $0,19 \%$ & $0,18 \%$ & $\leq 1,0$ \\
\hline Protein level & $93,63 \%$ & $97,42 \%$ & $\geq 75$ \\
\hline Fat level & $0,41 \%$ & $0,30 \%$ & - \\
\hline
\end{tabular}

The main components of collagen are proteins and other components in the form of water, ash and fat in small amounts. The collagen water content of patin fish skin produced, which is $6,55 \%$ lower than the commercial collagen water content of $6,68 \%$ and meets the collagen quality requirements that is $\leq 12^{12}$. 
The collagen protein content of patin fish skin is lower than that of commercial collagen protein and collagen quality requirements ${ }^{12}$. Differences in protein content can be caused by differences in the extraction methods used ${ }^{13}$. Differences that do not meet the collagen quality standards can also be caused by pretreatment processes that are still less effective.Ash content in patin fish skin collagen is lower than ash content in commercial collagen but slightly higher than collagen quality requirements ${ }^{12}$.The fat content in patin fish skin collagen is higher than the fat from commercial collagen. Patin fish skin collagen has a high fat content and ash which slightly exceeds the quality requirements of collagen. This can be caused by differences in the chemical composition contained in the leather raw material and the extraction techniques used.

Table 2: Yield Collagen of Patin Fish Skin and several other fish skins

\begin{tabular}{|l|l|l|}
\hline No & Collagen Source & Rendemen \% (bb) \\
\hline 1 & Patin fish Skin (Pangasius sp.) & 11,25 \\
\hline 2 & ASC Siam Patin fish Skin & 5,10 \\
\hline 3 & PSC Siam Patin fish Skin ${ }^{1}$ & 7,70 \\
\hline 4 & Cobia fish Skin (Rachycentron canadum) ${ }^{2}$ & 10,51 \\
\hline
\end{tabular}

Description: 1(Singh et al., 2011); 2(Ariesta, 2014),ASC) Acid Soluble Collagen; (PSC) Pepsin Soluble Collagen [4,14].

Yield is the percentage of collagen produced with the initial raw material. Rendemen shows the portion of raw materials that can be utilized and becomes an important parameter to determine the economic value, and effectiveness of a material or product. The results showed that patin fish skin collagen had a higher yield than Acid Soluble Collagen (ASC), Pepsin Soluble Collagen (PSC) Siamese patin fish, and cobia fish skin (Rachycentron canadum ${ }^{4}$ (Table 2 ).

The difference in the yield of collagen can be caused by differences in the extraction method, the concentration of the solution to remove non-collagen proteins, the type of material, the temperature and the length of time for production ${ }^{15}$.

The chemical composition of collagen is a parameter of the effectiveness of the deproteinization, defatting, demineralization, and extraction processes in the manufacture of collagen. Soaking in an alkaline and acidic solution aims to eliminate non-collagen proteins, as well as other components namely fats and minerals. This process is carried out in order to obtain high collagen protein content. The chemical composition of patin fish skin collagen and some other fish skin collagen is presented in Table 3.

Table 3. The chemical composition of metal collagen in patin fish skin

\begin{tabular}{|l|l|l|}
\hline Parameter & Commercial Collagen(ppm) & Patin fish skin collagen(ppm) \\
\hline $\mathrm{Cu}$ & 1,39 & 0,32 \\
\hline $\mathrm{Pb}$ & 0,12 & 0,07 \\
\hline $\mathrm{Fe}$ & 5,29 & 1,91 \\
\hline $\mathrm{Zn}$ & 0,45 & 0,45 \\
\hline
\end{tabular}

Metal analysis on patin fish skin is done so that the collagen product produced is guaranteed to be safe from metal contamination. The presence of metals in food can endanger health if the amount exceeds a specified threshold. Heavy metals are dangerous contaminants for consumers of food products, pharmaceuticals or cosmetics. The content of heavy metals for fish and their processed products specified is $0,3 \mathrm{mg} / \mathrm{kg}(\mathrm{Pb}) ; 0,5 \mathrm{mg} / \mathrm{kg}(\mathrm{Hg})$; and $0,1 \mathrm{mg} / \mathrm{kg}$ (As) ${ }^{16}$. The content of metals in commercial collagen and collagen of patin fish skins is below the threshold value and below the detection limit of the tool, so that the collagen of patin fish and commercial collagen is safe to use as a source nanogel preparations.

\section{PH Analysis}

The results of measurement of patin fish skin collagen $\mathrm{pH}$ were 6,0 at room temperature and commercial collagen which was 6,5 at room temperature. These results are lower than the collagen quality requirements of $6,5-8$, but slightly higher than the collagen $\mathrm{pH}$ of some collagen brands for cosmetics that are reported to range between 3,8 $-4,7$, and almost close when compared to the collagen $\mathrm{pH}$ of fish scales that range between $5,5-6,6^{12,17,18}$.

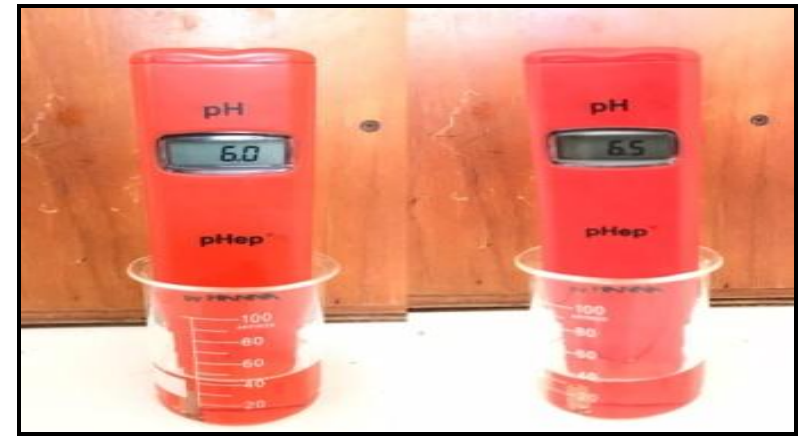

Figure 2: Results of $\mathrm{pH}$ analysis (a) of patin fish skin collagen; (b) commercial collagen

\section{Amino Acid Analysis}

Amino acids are the building blocks of proteins. Essential amino acids cannot be synthesized by the body but are highly needed by the body. Essential amino acids in collagen include isoleucine, leucine, lysine, methionine, phenylalanine, threonine, valine and arginine ${ }^{19}$. Collagen is a major structural component of connective tissue which covers nearly $30 \%$ of the total body protein. The basic collagen molecule is formed from three polypeptide chains 
that twist each other to form a triple helical structure with a unique amino acid composition, Gly-X-Y, at position $\mathrm{X}$ is proline and position $\mathrm{Y}$ is hydroxyproline ${ }^{20}$.

Nalinanon, et al said that type I collagen contained amino acids glycine, alanine, and proline in high amounts, whereas amino acids tyrosine and histidine were present in small amounts and did not contain cystine ${ }^{21}$. The presence of cystine in the resulting collagen showed deproteinization was not running optimally thus allowing the presence of cystine amino acids. The composition of the amino acids making up collagen can be seen in Table 4.

Table 4: Composition of amino acid collagen in patin fish skin

\begin{tabular}{|l|l|}
\hline Amino Acid & Result $(\mathbf{m g} / \mathbf{k g})$ \\
\hline Phenylalanine & 18393,05 \\
\hline Metionin & 9179,12 \\
\hline Cystine & $<48,42$ \\
\hline Histidine & 6140,05 \\
\hline Threonin & 26725,73 \\
\hline Arginine & 80918,44 \\
\hline Alanine & 83988,79 \\
\hline Valin & 15443,18 \\
\hline Isoleucine & 9139,72 \\
\hline Tyrosine & 2120,65 \\
\hline Glutamic acid & 87315,88 \\
\hline Serin & 32627,20 \\
\hline Glycine & 234381,88 \\
\hline Proline & 109404,17 \\
\hline Aspartic acid & 45684,84 \\
\hline Lycine & 30442,11 \\
\hline Leucine & 22438,43 \\
\hline
\end{tabular}

Functional Group Analysis with Fourier Transform Infrared (FTIR)

The results of analysis of patin fish skin collagen tested by FTIR can be seen in Figure 3.

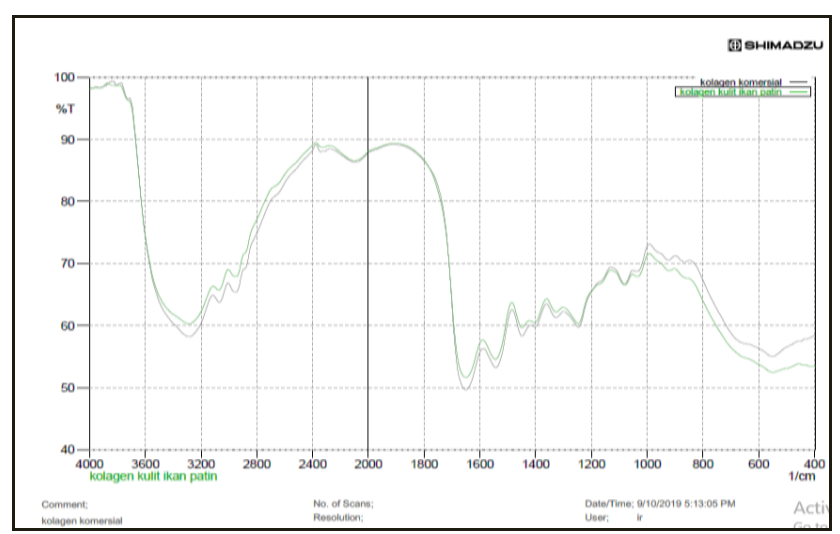

Figure 3: Infrared spectrum of patinfish skin collagen and commercial collagen

The amide A absorption peak of collagen from the skin of patin fish was detected at wave number $3286,7 \mathrm{~cm}^{-1}$ and commercial collagen $3286,7 \mathrm{~cm}^{-1}$ which showed vibration stretching $\mathrm{NH}$. The normal wave number of amide A, $\left(3400 \mathrm{~cm}^{-1}-3440 \mathrm{~cm}^{-1}\right)^{22}$. When the $\mathrm{N}-\mathrm{H}$ group in the peptide is affected by hydrogen bonds, its position will shift to a lower frequency.

The peak of amide B collagen uptake also shows the wave number in patin fish skin collagen 2947, $23 \mathrm{~cm}^{-1}$ and commercial collagen $2951,09 \mathrm{~cm}^{-1}$. Amide group B with absorption region at wave number $2915 \mathrm{~cm}^{-1}-2935 \mathrm{~cm}^{-1}$ or $2845 \mathrm{~cm}^{-1}-2865 \mathrm{~cm}^{-123}$. Wave numbers indicating amide $\mathrm{B}$ uptake are formed from asymmetric stretching $\mathrm{CH}_{2}{ }^{24}$.

Amide I wave number detected in patin fish skin collagen, namely $1651,07 \mathrm{~cm}^{-1}$ and commercial collagen 1651,07 $\mathrm{cm}^{-1}$ which showed the vibration stretching group $\mathrm{C}=\mathrm{O}$. Amide I is a typical functional group that makes up collagen. Amide I was detected in the range of wave numbers $1600 \mathrm{~cm}^{-1}-1690 \mathrm{~cm}^{-124}$.

Amide II which is a typical functional group of collagen that was detected in the skin of patin fish collagen, which is $1450,47 \mathrm{~cm}^{-1}$ and commercial collagen 1543,05 $\mathrm{cm}^{-1}$. Amide II uptake region, which is in the range of $1480 \mathrm{~cm}^{-1}$ $-1575 \mathrm{~cm}^{-1}$. The presence of the Amida II group shows the presence of $\mathrm{CN}$ stretching and $\mathrm{NH}$ bending 24 .

Amide III has an absorption area of $1229 \mathrm{~cm}^{-1}-1301 \mathrm{~cm}^{-1}$ ${ }^{24}$. The uptake region in patin fish skin collagen, which is $1246,02 \mathrm{~cm}^{-1}$ commercial collagen $1246,02 \mathrm{~cm}^{-1}$ indicates the presence of amide III functional groups that show $\mathrm{CH}$ stretching and $\mathrm{NH}$ bending. Amide III intensity is related to the existence of a triple helical structure ${ }^{7}$. This means that the extraction of patin fish skin collagen with water at a temperature of $40^{\circ} \mathrm{C}$ has not changed the collagen into gelatin which is characterized by the presence of a triple helical structure.

\section{CONCLUSION}

Non-collagen protein is removed maximally after the skin is soaked using $0.05 \mathrm{M} \mathrm{NaOH}$ for $3 \times 24$ hours. The value of collagen yield of patin fish skin obtained 11, $25 \%$. Chemical characteristics of collagen from patin fish skins include proximate analysis and amino acid composition. Proximate collagen of patin fish skin contains $6,55 \%$ water, ash $0,19 \%$, protein $93,63 \%$ and fat $0,41 \%$; while commercial collagen contains $6,68 \%$ water, $0,18 \%$ ash, $97,42 \%$ protein and $0,30 \%$ fat.

The dominant amino acid composition found in collagen is glycine, proline, alanine, arginine and glutamate. The metal content in commercial patin fish and collagen skin is below the threshold value so it is safe to use.

The physical characteristics of collagen produced were FTIR analysis showing the presence of amide group A $\left(3286,7 \mathrm{~cm}^{-1}\right)$, amide B $\left(2947,23 \mathrm{~cm}^{-1}\right)$, amide I $\left(1651,07 \mathrm{~cm}^{-}\right.$ $\left.{ }^{1}\right)$, amide II $\left(1450,47 \mathrm{~cm}^{-1}\right)$, and amide III $\left(1246,02 \mathrm{~cm}^{-1}\right)$, indicating that the resulting compound is collagen; and the $\mathrm{pH}$ value of patin fish skin collagen is 6,0 and commercial collagen 6,5 .

\section{REFERENCES}

1. Kementerian Kelautan dan Perikanan (KKP). 2015. Kelautan dan Perikanan dalam Angka 2015. Pusat data statistik dan informasi Sekretariat Jenderal Kementerian Kelautan dan Perikanan, Jakarta.

2. Sathivel, S., Yin, H., Prinyawiwatkul, W., King, J.M. dan Xu, Z. 2002. Economical methods to extract and purify Catfi sh oil. Published Article in the Louisiana Agiculture, LSU AgCenter, Department of Food Science, Baton Rouge La. 
3. Zuta, C.P., Simpson, B.K., Chan, H.M. dan Philips, L. Concentrating PUFA from Mackerel processing waste. J Am Oil Chem. Soc.2003; 80:933-936.

4. Singh, P., Benjakul, S., Maqsood, S., \& Kishimura, H. (2011). Isolation and characterisation of collagen extracted from the skin of striped catfish (Pangasianodon hypophthalmus). Food Chem.2011; 124:97-105.

5. Standar Nasional Indonesia 2891. (1992). Analisa kadar abu. Jakarta: Badan Standarisasi Nasional.

6. AOAC. 1995. Official Methods of Analysis of Association of Official Analytical Chemist. AOAC International. Virginia USA.

7. Muyonga JH, Cole CGB, Duodu KG.Characterisation of acids soluble collagen from skins of young and adult Nile perch (Lates niloticus). Food Chem.2004; 85:81-89.

8. AOAC (2005). Association of Official Analytical Chemist. Edisi Revisi. Edisi 18 2005. Official Methods of Analysis, Washington DC.

9. Zhou, P., \& Regenstein, J.M. Effects of alkaline and acid pretreatments on alaska pollock skin gelatin extraction. J Food Sci, 2005; 70(6):C392-C396.

10. Jaswir I, Monsur HA, Salleh HM. Nano-structural analysis of fish collagen extracts for new process development. African Journal of Biotechnology. 2011; 10(81):18847-18854.

11. Karim, A.A., \& Bhat, R.,Fish gelatin: properties, challenges, and prospects as an alternative to mammalian gelatins. Food Hydrocolloid, 2009; 23:563-576.

12. Standar Nasional Indonesia 8076:2014. (2014). Kolagen Kasar dari Sisik Ikan - Syarat Mutu dan Pengolahan. Jakarta: Badan Standarisasi Nasional.

13. Jamilah, B., Hartina, M.U., Hashim, D.M., \& Sazili, A.Q. (2013) Properties of collagen from barramundi (Lates calcarifer) skin. International Food Research Journal.2013; 20(2):835-842.

14. Ariesta, C. (2014). Ekstraksi dan karakterisasi kolagen dari kulit ikan cobia (Rachycentron canadum) (skripsi). Bogor: Departemen Teknologi Hasil Perairan, Fakultas Perikanan dan Ilmu Kelautan, IPB.
15. Potaros, T., Raksakulthai, N., Runglerdkreangkrai, J., \& Worawattanamateekul, W.Characteristics of collagen from nile tilapia (Oreochromis niloticus) skin isolated by two different methods. Kasetsart Journal2009; 43:584-593.

16. Standar Nasional Indonesia 7387-2009. (2009). Batas maksimum cemaran logam berat dalam pangan. Jakarta: Badan Standarisasi Nasional.

17. Peng, Y., Glattauer, V., Werkmeister, J.A., \& Ramshaw, J.A.M. Evaluation for collagen products for cosmetic application. J Cosmestic Sci.2004; 55, 327-341.

18. Hartati I., \& Kurniasari, L. Kajian produksi kolagen dari limbah sisik ikan secara ekstrasi enzimatis. Momentum.2010; 6 (1), 33-35.

19. Haris, M.A. (2008). Pemanfaatan limbah tulang ikan nila (Oreochromis niloticus) sebagai gelatin dan pengaruh lama penyimpanan pada suhu ruang (skripsi). Bogor: Departemen Teknologi Hasil Perairan, Fakultas Perikanan dan Ilmu Kelautan, IPB.

20. Friess W. Collagen - biomaterial for drug delivery. Eur J Pharm Biopharm.1998; 45:113-136.

21. Nalinanon S, Benjakul S, Visessanguan W, Kishimura H. Use of pepsin for collagen extraction from the skin of bigeye snapper (Priacanthus tayenus). Food Chemistry.2011; 104(2): 593-601.

22. Nagarajan, M., Benjakul, S., Prodptan, T., Songtipya, P dan Kishimura, H.Characteristic and functional properties of gelatin from splendid squid (Loliga formasana) skin as affected by extraction temperature. Food Hydrocolloid,2012; 20:389-397

23. Coates, J. (2000). Interpretation of infrared spectra, a practical approach. Di dalam: Meyers RA, editor. Encyclopedia of Analytical Chemistry. Chichester: John Wiley \& Sons Ltd.

24. Kong, J., \& Yu, S. Fourier transform infrared spectroscopic analysis of protein secondary structures. Acta bioch bioph sin,2007; 39 (8), 549-559. 